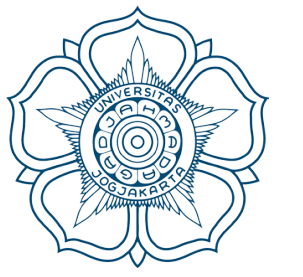

Author

: Henry Dianto Pardamean Sinaga

MIMBAR HUKUM

$\begin{array}{ll}\text { DOI } & : \text { http://doi.org/10.22146/jmh.27136 } \\ \text { Publisher } & : \text { Faculty of Law Universitas Gadjah Mada } \\ \text { URL } & : \text { jurnal.ugm.ac.id/jmh } \\ \text { E Issn } & : 2443-0994 \\ \text { P Issn } & : 0852-100 \mathrm{x}\end{array}$




\title{
LOSS (OF REVENUE) OF STATE WITHIN TAXATION CRIMES IN INDONESIA
}

\author{
Henry Dianto Pardamean Sinaga* \\ Directorate General of Taxation Republik Indonesia \\ Jalan Jenderal Gatot Subroto Kav. 40-42, South Jakarta, 12190
}

\begin{abstract}
The difference of state's tax loss amount between tax investigation, which has been completely declared by the Prosecutor, and judicial verdict can not be separated from the existence of the defendant's right to propose Witnesses/Experts, and or the dualism between the administrative penalties and the state's revenue loss. Due to the nature of tax and the ultimum remedium of tax investigation, the element (may) cause a losses (on income) of the state should be more legally certain as material offense, and must be explicitly regulated in Indonesian tax provisions which confirms the limitation of administrative penalties and tax criminal penalties.
\end{abstract}

Keywords: state's revenue loss, tax investigation, penalty.

\section{Intisari}

Masih timbulnya perbedaan jumlah kerugian pada pendapatan negara antara penyidikan pajak yang telah dinyatakan lengkap oleh Jaksa Penuntut dengan putusan peradilan tidak dapat terlepas dari adanya hak tersangka/terdakwa untuk mengajukan Saksi/Ahli yang dapat meringankannya, dan atau adanya dualisme pengaturan antara kerugian administrasi dengan kerugian (in revenue) Negara. Mengingat sifat alami pajak dan penyidikan pajak sebagai upaya akhir, maka unsur (dapat) menimbulkan kerugian (in revenue) negara adalah lebih mengandung kepastian hukum sebagai delik materiil, dan harus diatur secara eksplisit dalam ketentuan pidana pajak di Indonesia yang menegaskan batasan bahwa suatu perbuatan merupakan pelanggaran administrasi perpajakan atau merupakan tindak pidana perpajakan.

Kata Kunci: kerugian pada pendapatan negara, penyidikan pajak, sanksi.

\section{Pokok Muatan}

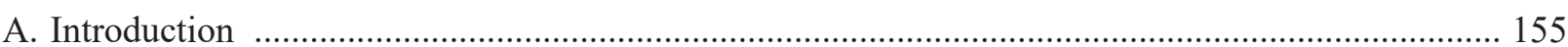

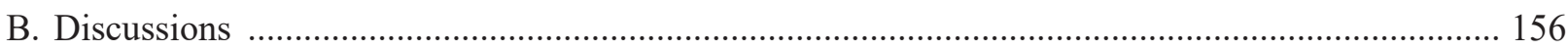

1. Element (possibility) Which Cause Losses (in Revenue) of State in the Field of Taxation

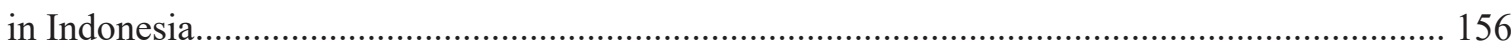

2. Regulations for Elements (Possibility) which Cause Losses (in Revenue) of State in the Field

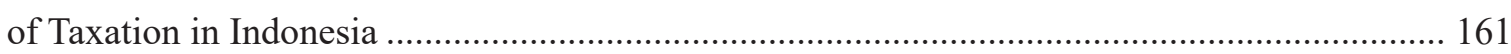

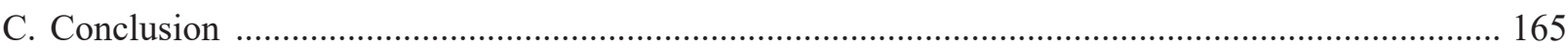

Correspondence address:_sinagahenrydp@gmail.com. Author is LPDP Scholarship Recepient at the Doctoroal Program of Legal Science of Universitas Diponegoro, This article is a private scientific study of the researcher and does not reflect the institution's opinion/policy. 


\section{A. Introduction}

Loss (of revenue) of the state in an act of taxation crime is one important element in the investigation of criminal acts in the field of taxation that occurred in Indonesia. This can be seen from the increasing number of state losses (in revenue) on the examination of initial evidence followed up with the investigation of taxation crime. In 2013 until 2015, the initial evidence checking report followed up with the taxation criminal investigation in each year has reached a total of 160 reports, 255 reports and 159 reports respectively. ${ }^{1}$ Further from each year, the case file of the investigation carried out by the Civil Servant Investigator (PPNS) of the Directorate General of Taxes (DGT) declared complete by the Public Prosecutor Office (Status P-21) indicates an increase in the amount of losses on state revenues where in 2013 there are 13 case files which have been declared complete with total loss on state income of Rp. 73,6 billion, in 2014 as many as 42 case files with total losses on state revenues of Rp. 271,1 billion, ${ }^{2}$ and in 2015 there are 65 case files with total losses on state revenues of Rp. 1.698,5 billion. ${ }^{3}$

Although there have been many filed cases that have been declared P-21, it turns out the amount of loss on the state's revenue is not necessarily the amount of losses on state revenues in the judicial decision. Some facts that show the difference are, among others: (a). The existence of District Court of Pontianak Decision Number 87/Pid.Sus/2016/ PN Ptk dated 19 April 2016 which decided on imprisonment and a fine of Rp. 377,41 million,from a loss on state revenues of Rp. 4,21 billion demanded by the Public Prosecutor. The fine of Rp. 377,41 million were reinforced in the appeal decision of the High Court of Pontianak Decision Number 55/PID.SUS/2016/PT PTK dated 9 June 2016 and Supreme Court Cassation Decision Number 1806 K/
PID.SUS/2016 dated 23 November 2016; (b). The existence of District Court of Pekanbaru Decision No. 229/Pid.Sus/2014/PN.Pbr dated 20 November 2015 which decided the tax crime with a loss on state revenue of Rp. 1,1 billion. ${ }^{4}$ However, the decision was corrected by an appeal decision High Court of Pekanbaru Decision No. 19/PID.SUS/2015/PT.PBR dated 11 Mei 2015 with a loss on state revenues of Rp. 5,59 billion; (c). The existence of District Court of Palembang Decision No. 394/Pid.sus/2015/ PN Plg dated 15 December 2015 which freed the defendant from the indictment and from the claim of loss on state income of Rp. 99.39 billion, of which one consideration states that: i). the opinion of the Criminal Expert, which the defendant proposed, state that the criminal offense shall be committed if the administrative elements are not met by the Taxpayer (Wajib Pajak) and shall result in financial loss of the state of the tax law which is part of the civil law and the tax nature (collect taxes as much as possible) and arranging to maximize tax levies, and ii). The Loss Counting Expert on State Revenue cannot explain how and how much the state losses incurred as a result of the Defendant's actions; (d). The existence of Supreme Court Cassation Decision Number 55 K/PID.SUS/2014 dated 16 June 2014 who granted the appeal of the Public Prosecutor by imposing taxation crime on the defendant with a total loss of state revenue of Rp. 4.73 billion, and at the same time canceled the decision of the District Court of Surakarta Number: 12/Pid.Sus/2013/ PN.Ska dated June 10, 2013 which freed the defendant on one of the prosecutor's charges against the defendant who is deemed to have caused losses on state revenues of Rp. 4.73 billion; and (e). The decision of Central Jakarta District Court No. 234/ PID.B/2011/PN.JKT.PST dated 15 March 2012 and the Decision of the High Court of Jakarta No. 241/ PID/2012/-PT.DKI dated 23 July 2012 which freed

\footnotetext{
Directorate General of Taxation Republik Indonesia, 2015, Anual Report 2015, Directorate General of Taxation Republik Indonesia, Jakarta, p. 66.

Directorate General of Taxation Republik Indonesia, 2014, Anual Report 2014, Directorate General of Taxation Republik Indonesia, Jakarta, p. 65.

Directorate General of Taxation Republik Indonesia, 2015, Anual Report 2015, Op.cit., p. 67.

Supreme Court of the Republic of Indonesia, "Putusan PN PEKANBARU Nomor 229/Pid.Sus/2014/PN. Pbr Tahun 2014", https://putusan. mahkamahagung.go.id/putusan/4e67ddd85f9ea66bdef51d16abe1dd52, accessed on 28 June 2017.
} 
the Defendant SL. ${ }^{5}$ However in Supreme Court Cassation Decision Number 2239 K/PID.SUS/2012 dated 18 December 2012 canceled the ruling and granted the appeal of the Public Prosecutor (JPU) by ruling the imprisonment of the Defendant SL and who have caused a loss to the state revenue of Rp. 1.25 trillion.

There is still a difference in the calculation of the amount of losses on state revenues between the investigation of criminal acts in the field of taxation which has been declared P-21 with judicial decision either at the first level, appeal, cassation, or review, the right of suspect/defendant to propose Witness/Expert who can mitigate their sentence, and the existence of different perspectives of the understanding regarding regulations on losses (in revenue) of state, there are two main issues that will be searched for in this article. First, what are the elements (possibility) which cause losses (in revenue) of state in the field of taxation in Indonesia? Second, how to formulate regulations for elements (possibility) which cause losses (in revenue) of state in the field of taxation in Indonesia?

\section{B. Discussions}

1. Element (possibility) Which Cause Losses (in Revenue) of State in the Field of Taxation in Indonesia

The occurrence of losses (in revenue) of the state is one element that confirms that there has been a criminal offense in the field of taxation as stipulated in several articles on the criminal provisions of the applicable tax laws that basically refers to the phrase "so as to cause losses on state revenues" or the phrase "thus causing losses to the state". The prevailing taxation legislation also states that the investigation of criminal offenses in the field of taxation must be done through the mechanism of proof of preliminary examination. ${ }^{6}$

The existence of the phrase "so as to cause losses on state revenues" in the prevailing tax laws and regulations can be seen in the taxation crimes provisions in Article 38 of Law No. 6 of 1983 regarding General Provisions and Procedure of Taxation (Undang-Undang Ketentuan Umum dan Tata Cara Perpajakan, hereinafter UU KUP) as Has Been Amended Several Times Lastly by Law No. 16 of 2009 in the case of omissions which may result in a loss to the state income, in Article 39 paragraph (1) of UU KUP in the event of deliberate harm to the state income, and in Article 39 paragraph (3) of UU KUP in the case of a trial in order to file a request for restitution or tax compensation or improper tax crediting is detrimental to the state. Meanwhile the phrase "thus causing losses to the state" can be seen in Article 24 and Article 25 paragraph (1) of Law No. 12 of 1994 regarding Amendment to Law No. 12 of 1985 regarding Land and Structure Tax (Undang-Undang Pajak Bumi dan Bangunan, hereinafter UU PBB). ${ }^{7}$

The phrase "so as to possibly cause losses (in revenue) of the state" in the provisions of criminal offense in the regulations of taxation itself, is in fact not interpreted uniformly in its implementation practice due to the absence of an explicit regulation. This is very different from several (positive) laws outside Indonesian tax laws and regulations which clearly govern the notion of the phrase "losses (in revenue) of the state" and/or other similar phrases such as stipulated in Article 1 subparagraph 15 of Law No. 15 of 2006 regarding Supreme Audit Board (UU BPK) and Article 1 subparagraph 22

\footnotetext{
Abdul Ficar Hadjar, et al., 2014, Menghukum Pengemplang Pajak: Hasil Eksaminasi Publik atas Putusan Mahkamah Agung Dalam Perkara Tindak Pidana Pajak dengan Terdakwa Suwir Laut, The Indonesian Legal Resource Center dan Indonesian Corruption Watch, Jakarta, p. 11. Article 43A paragraph (1) Law No. 6 of 1983 regarding General Provisions and Procedure of Taxation as Has Been Amended Several Times Lastly by Law No. 16 of 2009 ( KUP Law).

Until the time of writing, the imposition of Land and StructureTax is done by the Government of Regency/City and Central Government (in this case the Directorate General of Taxes). Rural Land and Structure Tax and Urban are included in the the Type of Tax of Regency/City as regulated in Article 2 paragraph (2) letter j of Law Number 28 of 2009 regarding Regional Tax and Levy. Meanwhile Land and Structure Tax which covers the tax objects within the plantation sector, forestry sector, mining sector, and other sectors (other than tax object within the plantation sector, forestry sector and mining sector which are not in regency/city region) as regulated in Minister of Finance of Republic Indonesia Regulation Number 139/PMK.03/2014 dated 10 July 2014 regarding Classification and Stipulation of the Sale Value of Tax Objects as the Basis of Land and Structure Tax.
} 
of Law No. 1 of 2004 regarding State Treasury (Treasury Law) which defines the phrase "Losses of State/Region", ${ }^{8}$ Elucidation of Article 32 paragraph (1) of Law No. 31 of 1999 regarding Elimination of Crime of Corruption (UU PTPK) which defines the phrase "losses to state revenue", and Constitutional Court Decision No. 003/PUUIV/2006 dated 24 July 2006 which states that the relationship of the word "possible" and "cause losses to state revenue" is displayed in two extreme relationships that are obviously detrimental to the state or may cause harm, where to consider the special and concrete circumstances surrounding the events that occur must be done by experts in state finance, state economy, and experts in the analysis of the relationship of an individual with loss. ${ }^{10}$ The Consitutional Court also affirms that the criminal act of corruption is classified as a formal offense, in which the elements of deed must have been fulfilled, and not as material offense, which requires the consequences of an act in the form of such loss to occur, so therefore the word "possible" before the phrase "cause losses to state's revenue or state's economy" on the criminal act of corruption, can be viewed in similar meaning as the word "possible" present before the phrase "jeopardize the security of people or goods, or the safety of the country in a state of war", as stipulated in Article 387 KUHP. ${ }^{11}$

In addition to some laws outside the laws of taxation, some experts also argue about elements that possibly may harm the state revenue or state economy. Romli Atmasasmita opines that the presence of the word "possible" before the phrase "cause losses to state's revenue or state's economy" means that there is no need for financial losses to have actually happened, but rather that with "so as to possibly cause losses to state's revenue or state's economy" it is considered that the core element of the offense has been fulfilled. ${ }^{12}$ Further, Romli Atmasasmita also asserted that in terms of grammatical and systematic interpretation then the formulation of Article 2 paragraph (1) UU PTPK in which there is the word "possible" must be interpreted holistically that is related to the initial sound of the sentence in that chapter which must be read in one breath, not separate and partial because it has fulfilled the principles of lex scripta, lex certa and lex stricta. ${ }^{13}$ Erman Rajagukguk argue that the words " $[\ldots]$ cause losses to state's revenue or state's economy $[\ldots]$ " which can be interpreted according to the will of anyone who read it does not bring legal certainty because the action or event is not real or have not necessarily happened and there is no set understanding of the amount involved. ${ }^{14}$ Further, Andi Hamzah opines that the word "possible" may be accepted with the interpretation of utilizing experts as it is not possible to simply term it as "potential to cause losses in state revenue". In the process of evidentiary proof, each party may file an accountant, if the Judge is still hesitant on the accountant's explanation, then the judge must decide to free the defendant (in dubio proreo). ${ }^{15}$

Further regarding the losses on state revenues, Widyo Pramono is of the opinion that one of the foundations in determining the element of loss on the state revenue is actually the tax debt calculated and the tax audit resulting in the issuance of tax assessment letters (SKP) conducted after the criminal justice process. ${ }^{16}$ This is also confirmed in the authority of Director General (DG) of Taxes

\footnotetext{
Article 1 sub paragraph 15 of Law No. 15 of 2006 and Article 1 subparagraph 22 of Law No. 1 of 2004 regarding State Treasury stipulates that what is referred to as State/Regional Loss is the lack of lack of money, securities, and goods, which is real and specific in number as a result of unlawful acts either intentionally or negligently.

Elucidation of Article 32 paragraph (1) Law No. 31 of 1999 regarding Eradication of the Crime of Corruption states that what is referred to as real loss in state revenue is a loss of state revenue that can already be calculated in number based on the findings of authorized agencies or appointed public accountant.

10 Constitutional Court Decision (MK) No. 003/PUU-IV/2006 dated 24 July 2006, p. 72.

Ibid., p. 71.

Ibid., p. 52.

Ibid., p. 53.

Ibid., p. 57.

Ibid., p. 61.

Widyo Pramono, "Penyamaan Persepsi dan Kerjasama dalam Pemeriksaan Di Bidang Perpajakan untuk Mendukung Optimalisasi Penerimaan
} 
in issuing Tax Underpayment Assessment Letter $(\mathrm{SKPKB})^{17}$ or Additional SKPKB ${ }^{18}$ against a court decision having a permanent legal force with respect to a WP who commits a criminal act of taxation or other criminal offense which may result in a loss to the state revenue. Then there is also the authority of the Minister of Finance to request the Attorney General to terminate the investigation of taxation crime if the WP has paid the amount of losses on state revenues, which is calculated based on the minutes of the examination of experts, amounting to: a). the amount of tax which is not paid or paid less or that should not be refunded (in the case of a criminal act in the field of taxation that is suspected in connection with Article 38 or Article 39; or b). the amount of tax in the tax invoice, the evidence of tax collection, proof of tax withholding, and/ or proof of tax deposit (in the case of a criminal offense in the field of alleged taxation related to Article 39A of UU KUP). The amount of tax above plus the administrative sanction in the form of a fine of 4 (four) times the amount of tax which is not paid or paid less or which should not be refunded or 4 (four) times the amount of tax in the tax invoice, tax collection evidence, tax deduction evidence, and/or proof of tax deposit. ${ }^{19}$

In view of the basis of the criminal investigation of taxation shall be from the examination of the preliminary evidence as affirmed in Article 43A paragraph (1) UU KUP where then on Article 1 subparagraph 26 UU KUP it is affirmed that preliminary evidence is a condition, act, and/or evidence in the form of information, writings, or objects that may provide a strong indication that there is or has been a criminal act in the field of taxation carried out by anyone who may cause a loss to the state revenue. This implies that it is necessary to better understand the offense in the taxation crime to determine whether or not it meets the requirements of a formal offense or material offense. Further, several law experts in Indonesia holds opinions regarding this formal offense or material offense. Eddy O. S. Hieriej opines that formal offense is an offense which puts great emphasis on action, while material offense is an offense which emphasizes causation. ${ }^{20} \mathrm{~A}$. Z. Abidin and Andi Hamzah emphasizes that in a formal offense it is said that only certain actions can be criminalized while in a material offense when there is a certain cause, whether or not an action has occurred..$^{21}$ Schaffmeister, et al. States that formal offense emphasizes actions, separated from the causes that might occur, the action itself is already in contravention with either prohibitions or orders and can be criminalized, while in material offense, what is prohibited and can be criminalized is causation where the action, although important, is already contained within. ${ }^{22}$

The existence of the necessity of fulfillment of element of crime in a crime confirms that the criminal act of taxation must also have legal certainty towards the offense. In the Academic Paper Draft (Bill) of UU KUP states that the taxation penalty fulfills formal offense, as the argument is based on the following quotation:

Based on systematic interpretation of memorie van toelichting Article 2 paragraph (1) of Law No. 31 of 1999 as has been reviewed based on Supreme Court Decision Number 03/PUU-IV/2006 which states that "the word possible before the phrase so as to

Negara", Yustisia, Vol. 5, No. 1, January - April 2016, p. 12.

17 Article 14 paragraph (3) of Government Regulation No. 74 of 2011 regarding Procedure for the Implementation of Rights and Fulfillment of Tax Obligations (State Gazettes of the Republic of Indonesia of 2011 Number 162, Additional State Gazettes of the Republic of Indonesia Number 5268).

18 Article 15 paragraph (4) Government Regulation No. 74 of 2011 regarding Procedure for the Implementation of Rights and Fulfillment of Tax Obligations (State Gazettes of the Republic of Indonesia of 2011 Number 162, Additional State Gazettes of the Republic of Indonesia Number 5268).

19 Article 62 Government Regulation (PP) No. 74 of 2011 regarding Procedure for the Implementation of Rights and Fulfillment of Tax Obligations (State Gazettes of the Republic of Indonesia of 2011 Number 162, Additional State Gazettes of the Republic of Indonesia Number 5268).

20 Eddy O. S. Hieriej, 2014, Prinsip-Prinsip Hukum Pidana, Penerbit Cahaya Atma Pustaka, Yogyakarta, p. 103.

21 A. Z. Abidin and Andi Hamzah, 2010, Pengantar dalam Hukum Pidana Indonesia, Yarsif Watampone, Jakarta, p. 129, .

22 D. Schaffmeister, et al, 2007, Hukum Pidana, Citra Aditya Bakti, Bandung, p. 30. 
cause losses to the revenue or economy of the state displays that criminal offense in taxation is a formal offense, where the criminality in corruption is proven by fulfilling elements of deeds that have been formulated rather than with consequences that arise." In line with this interpretation, tax offense contained within UU KUP is a formal offense which then means that state losses is accidentalia van het delict and not essentialia van het delict so the public prosecutor is not obliged to prove as such. The word "loss" in the core of the loss to state revenue is a guideline for judges to determine the severity of the sanctions imposed. Therefore to provide legal certainty, then it is for betterment that the word "possible" before the phrase "so as to cause losses to the revenue to the state" is eliminated so the phrase "so as to cause losses to the revenue to the state" becomes the core element of the offense which shall be proven by the public prosecutors. ${ }^{23}$

Based on the quotation above, the existence of the phrase "so as to possibly cause losses to state's revenue" in the criminal provisions of UU KUP in fact will be amended in the criminal provisions of the Draft of UU KUP to the phrase "so as to cause State Revenue Losses in the Taxation Sector". Regarding the changes, the academic paper of the Draft of UU KUP merely explains that it is to provide more legal certainty so that the word "possible" before the phrase causing a loss on the state revenue is better to be removed so the phrase "cause losses to the state revenue" becomes a core part of the offense that should be proven by the public prosecutor. Then, there is an explanation of the word "losses" at the core of the loss on state revenues which is considered to be a guide for the judge to determine the severity of the punishment to be imposed. ${ }^{24}$ Additionally, the change from "cause losses to the state revenue" to "State Revenue Losses in the Taxation Sector" increasingly affirms the close interconnection between UU KUP with Law No. 17 of 2003 regarding State Finances (UU $\mathrm{KN}$ ) where if connected with Article 1 subparagraph 1 of UU KN hence the financial losses of the state shall be construed as an act which causes losses to all rights and obligations of the state which can be assessed by money, and everything in the form of money or in the form of goods which may be the property of the state in connection with the exercise of such rights and obligations. Further in Article 2 letter a of UU KN it is further stressed that one of the rights of the state is the right to levy taxes.

In addition to the explanation on the changes of the phrase "so as to possibly cause losses to state's revenue" to the phrase "so as to cause State Revenue Losses in the Taxation Sector" in the Draft of UU KUP, there is an explanation which affirms that all the tax offenses that exist in UU KUP is a formal offense can lead to potential legal uncertainty in the implementation. Referring to the imposition of criminal sanction in taxation which is ultimum remedium ${ }^{25}$ and the existence of Article 43A paragraph (1) UU KUP, Article 1 subparagraph 26 UU KUP, Article 8(3) UU KUP, ${ }^{26}$ Article 25 PMK No. 239/PMK.03/2014 which regulates the payment of a deductible value of the state revenue (which is two-fifths of the amount of payment in respect of disclosure of unlawful deeds) of payment of disclosure of unlawful deeds that are inconsistent with the actual circumstances as long as payment

\footnotetext{
23 National Legal Development Board of the Ministry of Justice and Human Rights of the Republic of Indonesia, "Laporan Akhir Penyelarasan Naskah Akademik Rancangan Undang-Undang Tentang Ketentuan Umum Dan Tata Cara Perpajakan", http://www.bphn.go.id/data/documents/ Penyelarasan-NA-RUU-Ttg-Ketentuan-Umum-\&-Tata-Cara-Perpajakan.PDF, accessed on 29 March 2017.

24 National Legal Development Board of the Ministry of Justice and Human Rights of the Republic of Indonesia, "Laporan Akhir Penyelarasan Naskah Akademik Rancangan Undang-Undang Tentang Ketentuan Umum Dan Tata Cara Perpajakan", http://www.bphn.go.id/data/documents/ Penyelarasan-NA-RUU-Ttg-Ketentuan-Umum-\&-Tata-Cara-Perpajakan.PDF, accessed on 29 March 2017.

25 Elucidation of Article 13A Law No. 6 Year 1983 (KUP Law) as has been modified many times, last modified into Law No. 16 Year 2009 regarding General Provisions of Tax (State Gazettes of the Republic of Indonesia of 2009 Number 62, Additional State Gazettes of the Republic of Indonesia Number 4999).

26 Article 8(3) KUP Law: "Although the inspection has been undertaken, but no investigation action has been conducted on the unlawfulness of the Taxpayer as referred to in Article 38, the unlawfulness of the Taxpayer's conduct shall not be investigated, if the Taxpayer voluntarily discloses his/her misconduct accompanied by payment of the shortage of the amount of taxes actually owed and administrative sanctions in the form of a fine of $150 \%$ of the amount of taxes that are underpaid".
} 
is made before the notice of commencement of the Inquiry (SPDP) is submitted to the prosecutor through the National Police, ${ }^{27}$ and Article 44B UU KUP and PMK-55/2016 which stipulates that if the losses on the state revenue have been settled, the investigation may be terminated (noting that as long as the court proceedings have not commenced), it carries more legal certainty if the criminal offense in taxation which possibly cause losses (in revenue) of the state is a material offense. This is also reinforced by the language of Article 38, Article 39 paragraph (1), Article 39 paragraph (3), Article 39A UU KUP, and Article 24 and Article 25 paragraph (1) UU PBB which affirms the imposition of sanctions on the offender in the form of imprisonment and a fine of several multpiles for certain taxes. Thus, there is a requirement of criminal penalty of fine in addition to imprisonment for the violation of Article 38, Article 39 paragraph (1), Article 39 paragraph (3), Article 39A UU KUP, and Article 24 and Article 25 paragraph (1) UU PBB indicates an affirmation that an act in violation of those articles which may result in losses (in revenue) of the state.

As for the word "possibility" before the phrase "so as to cause harm to the state's revenue", in general, it should be interpreted in its entirety, and it is not interpreted that the act or incident is not real or not necessarily to have occurred but must be illustrated as an act which has obviously created potential loss to the state revenue in the tax sector as its concrete event is explained by at least by the expert on regulatory of taxation and loss calculation of state revenues. While specifically (in the context of taxation) it should be understood that the purpose of the phrase "possibly cause losses to state revenues" refers to the already occurring or still is a potential occurrence to happen can already be charged as a crime in accordance with tax offenses, or in other words in the case of tax criminal investigation, there is no need for any real loss but it is enough that potential losses may occur to be charged with said article. This is due to the following three things: 1) nature of tax criminal investigations that are still strong allegations, 2) nature of the definition of the tax itself as a compulsory contribution of a coercive state under the Law with no direct reward, ${ }^{28}$ and 3) self-assessment system that is applicable in Indonesia, ${ }^{29}$ so that the calculation of losses (in revenue) of the state will be certain if it has obtained a decision of a court that has final and binding legal force (inkracht). ${ }^{30}$

The existence of opinion in the Academic Paper on the Draft of UU KUP which equates the element of losses (in revenue) of the state in the element of criminal offense of taxation with elements can harm the state finance or economy

\footnotetext{
27 Ministerial Regulation of the Finance Minister of the Republic of Indonesia Number 239/PMK.03/2014 dated 22 December 2014 regarding Procedures of Examination of Evidence of Commencement of Criminal Acts in the Taxation Sector, states: (1) In the event that an Initial Examination Inspection is followed up with an Investigation, payment for the disclosure of an act of unlawfulness that does not comply with the provisions referred to in Article 23 paragraph (4), paragraph (5), and paragraph (6) and/or is inconsistent with the actual circumstances does not eliminate all losses of state revenues. (2) The payment referred to in paragraph (1) may be considered as a deduction of the value of loss of state revenue as long as the payment is made before the notice of commencement of the Inquiry and shall be submitted to the public prosecutor through investigator of the National Police of the Republic of Indonesia. (3) Payments meeting the provisions referred to in paragraph (2) shall not be requested to be refunded by the Taxpayer. (4) The amount that can be calculated as a deduction of the value of loss on the state income as referred to in paragraph (2) is two-fifths of the amount of payment in the framework of disclosure of the unlawfulness of his/her actions. (5) An example of how to calculate the amount that can be calculated as a deduction of the value of loss on the state income referred to in paragraph (4) is as contained in the Attachment which is an integral and unseparable part of this Ministerial Regulation".

28 Article 1 subparagraph 1 KUP Law.

29 The understanding of the term self assessment, in the context of the tax collection system in Indonesia, all Taxpayers who have fulfilled subjective and objective requirements: (a). Obligatory to register themselves at the Directorate General of Taxes office (Article 2 paragraph (1) in conjunction with Article 4 paragraph (1) of the KUP Law); (b). Compulsory fill out the SPT correctly, complete, and clear and sign and submit it to the office of the Directorate General of Taxation (Article 3 paragraph (1) KUP Law); (c). Taking own SPT in the place specified by the Director General of Tax (Article 3 paragraph (2) KUP Law); and D). Obligate to pay or deposit their own tax payable by using Tax Payment Deposit (SSP) by not relying on the existence of tax assessment letters (Article 10 paragraph (1) jo. Article12 paragraph (1) KUP Law).

30 Inkracht in relation to criminal law can not be separated from the Elucidation of Article 2 paragraph (1) of Law No. 22 of 2002 on the clemency stating that the meaning of incracht is: (1) the decision of the first court which is not submitted for appeal or submitted for cassation within the period as stipulated in Law Number 8 Year 1981 regarding the Criminal Procedure Code (KUHAP), (2) an appeal court decision not appealed within the period set out in the Criminal Procedure Code, (3) the decision of appeal. It should be added that in Article 268 paragraph (1) of the Criminal Procedure Code, it is emphasized that the request for Judicial Review of a decision does not suspend or stop the implementation of the decision.
} 
in the criminal offense of corruption, according to the Author is not in accordance with legal certainty. According to the Author, the argument of the Academic Paper on the Draft of UU KUP which equates the elements can harm the state finance or economy in the corruption offense as a formal offense in the offense of taxation has ignored Article 4 UU PTPK $^{31}$ and Article 59 paragraph (1) of Treasury Law, ${ }^{32}$ where one of the key spirit of UU KUP itself is to support a more stable tax revenue so that the actual emphasis of the tax criminal provisions is as a last resort (ultimum remedium). The emphasis of tax criminal provisions as ultimum remedium can be seen from the existence of Article 43A paragraph (1) and Article 1 subparagraph 26 UU KUP which states that prior to the tax investigation, there must be an examination of the preliminary evidence with one of its stages is to provide an opportunity for the Taxpayer to express his own unlawfulness as the mechanism of self-disclosure of unlawfulness is regulated in Article 8 (3) UU KUP and PMK No. 239/PMK.03/2014. Even as the investigation proceeds, the Taxpayer still has the opportunity to request a suspension of an investigation as the mechanism stipulated in Article 44B UU KUP and PMK-55/PMK.03/2016, as long as it has not been transferred to court.

\section{Regulations for Elements (Possibility) which Cause Losses (in Revenue) of State in the Field of Taxation in Indonesia}

The investigation of tax crime is conducted in the case of sufficient initial evidence ${ }^{33}$ which in the inspection report of the preliminary evidence there must be fulfilled several facts which at least illustrate: 1) alleged article suspicion, 2) modus operandi, 3) tempus delicti, 4) locus delicti, 5) alleged perpetrators of criminal acts in the field of taxation, 6) prospective witnesses, 7) evidence materials, and 8 ) any loss to state revenue. ${ }^{34}$ However, as in a preliminary proof examination, where a violation is concerning the administrative action of taxation then it shall be subject to administrative sanction or where a criminal offense has occurred then it shall be subject to criminal sanctions, ${ }^{35}$ the issue of a strict arrangement between an offense of tax administration or a tax crime does not yet exist to date.

The absence of strict regulations concerning the category of acts in the form of violations of tax administration or tax crime shall, in certain cases, result in dualism of the treatment of application of sanctions, whether it be criminal or administrative. One example is Tax Court Decision Number PUT56245/PP/M.XIVA/15/2014 dated 17 October 2014 which refuses the appeal of the appellant (WP) against the positive correction of business circulation, the negative correction of cost of goods sold (HPP), and the positive correction of the gross income deducted by the Appellant failing to submit the Annual Income Tax (Pph) Return (SPT) of Institutions and did not submit bookkeeping on the grounds that the documents were lost/burned. The act of the Institutional WP is only subject to administrative sanctions, whereas Article 28 paragraph (1) of UU KUP stipulates that the Insitutional Taxpayer in Indonesia is obliged to maintain bookkeeping, then in the criminal provisions of taxation it has also affirmed that the imposition of criminal sanctions on any person not

\footnotetext{
1 Article 4 Law No. 31 Year 1999 regarding Corruption Eradication states: "The return of loss of state revenue or state's economy does not eliminate the criminalization of the offender as referred to in Article 2 and Article 3". Further in the Elucidation of Article 4, also affirms that in the event that the perpetrator of corruption as referred to in Article 2 and Article 3 has fulfilled the elements of the aforementioned article, the return of the state revenue or economy shall not eliminate the criminal sanction against the offender. The return of loss of state revenue or state's economy is only one mitigating factor.

32 Article 59 paragraph (1) Law on State Treasury and its Elucidation affirms that any state losses caused by unlawful acts shall be replaced in accordance with the applicable legislation provisions which with the settlement of such losses the state may be recovered from the loss already incurred.

33 Article 30 paragraph (1) letter a PMK No. 239/PMK.03/2014 dated 22 December 2014 regarding Procedures of Examination of Evidence of Commencement of Criminal Acts in the Taxation Sector.

34 Form 79 Circular Letter of (SE) Director General of Taxation Number SE-23/PJ/2015 dated 25 March 2015 regarding Technical Instructions of Examination of Evidence of Commencement of Criminal Acts in the Taxation Sector.

35 Elucidation of Article 38 KUP Law.
} 
submitting SPT or submitting SPT but the contents are untrue or incomplete either due to negligence, as provided for in Article 38 of UU KUP, or by intent, as provided in Article 39 paragraph (1) letter c and/ or letter d of UU KUP. Comparing it to District Court of Pontianak Decision Number 87/Pid.Sus/2016/PN Ptk dated 19 April 2016, High Court of Pontianak Decision Number 55/PID.SUS/2016/PT PTK dated 9 June 2016, and Supreme Court Cassation Decision No. 1806 K/PID.SUS/2016 dated 23 November 2016 which decided the imprisonment and penalty for not submitting the Annual Income Tax Return of the Income of Individual Taxpayer and the Value Added Tax (PPN).

All this while, a criminal act of taxation in Indonesia is only based on the fulfillment of at least two evidences of elements in the criminal offense of taxation, so it is necessary a deep understanding of the imposition of sanctions taxation should be identified with ultimum remedium from a tax fraud, or tax evasion (debility/ evasion of tax). This understanding is clearly different from the understanding of the imposition of sanctions for violations of tax administration identical to tax avoidance. Although tax laws and regulations are not officially regulated on tax avoidance or tax evasion, they are very common in various taxation literature. In Black's Law Dictionary the two definitions are very different from those in which tax avoidance is defined as "the act of taking advantage of legally available tax-planning opportunities in order to minimize one's tax liability", ${ }^{36}$ while tax evasion is defined as "the willful attempts to defeat or circumvent tax law in order to illegally reduces one's tax liability. Also termed tax fraud". ${ }^{37}$

Furthermore, in relation to the calculation of the value of the state's losses (in revenue) in taxation crimes, tax evasion must be understood through the meaning of fraud itself, which, according to Theodorus M. Tuanakotta, is an unlawful act involving malicious intent, fraud, concealment and misuse of trust, aimed at taking ill-gotten advantage. ${ }^{38}$ Similarly, according to Mark F. Zimbelman, et al. which states that cheating is a fraud that represents something material, incorrect, and intentionally or haphazardly done to be trusted and followed up by the victim, so that the victim ends up accruing a loss. ${ }^{39}$

In relation to the formulation of the element of taxation criminal offense, the tax crime to be presumed must describe the facts of mutual correlation between circumstantial evidence and corroborating evidence in accordance with criminal procedural law in which almost all criminal verdict of taxation is always accompanied by evidence in the form of expert information (at least tax regulation experts and experts on losses on state income) as regulated in Article 184 paragraph (1) and Article 1 point 28 KUHAP, it can be ascertained that the expert's statement is very important in explaining an act as a taxation crime and explaining the act is considered to cause losses (in revenue) of the state, and not considered to be an administrative offense. This also deals with the obligation of a person who is consulted as an expert to provide an expert opinion for the purpose of justice ${ }^{40}$ and the authority of the investigator who may seek expert opinions or those who have special expertise, ${ }^{41}$ except when it relates to his honour and dignity, his job or occupation which requires confidentiality, then the expert may refuse to provide such information. ${ }^{42}$

In view of the importance of an expert in a taxation crime (whether in the form of evidence of expert opinionor in the form of documentary evidence in the case of an expert unable to attend the hearing), there exists the right of a suspect or

\footnotetext{
Bryan A. Garner (Ed.), 2004, Black's Law Dictionary, West Publishing Co, St. Paul, MN, p. 1500.

Ibid., p. 1501.

Theodorus M. Tuanakotta, 2013, Mendeteksi Manipulasi Laporan Keuangan, Penerbit Salemba Empat, Jakarta, p. 28.

Mark F. Zimbelaman, et al., Translated by Novita Puspasari, et al., 2014, Akuntansi Forensik, Penerbit Salemba Empat, Jakarta, p. 8.

Article 179 paragraph (1) General Provisions of Indonesia Criminal Law.

Article 120 paragraph (1) General Provisions of Indonesia Criminal Law.

Article 120 paragraph (2) General Provisions of Indonesia Criminal Law.
} 
defendant to request for a witness or a person with special expertise favourable to his case, ${ }^{43}$ to avoid potential lawsuits against experts in connection with false complaints or defamation complaints ${ }^{44}$ or in connection with disclosing a confidential secret ${ }^{45}$ or in connection with the act because of the wrongness in causing damage to others, ${ }^{46}$ or other Articles of similar laws, it must absolutely be considered that an expert is truly a capable, independent and objective expert in providing information and opinions. In particular, so that the expert is not only questioned in the investigation but also has the right to obtain a comprehensive picture of the existing facts which the expert has to explain in respect of his competence, including to show evidence that has been seized by the PPNS DJP in respect with the allegations of criminal offense and the incidence of losses (in revenue) of the state, so there is no bias in determining whether an act is a criminal offense in the field of taxation that is in accordance with the elements of the article that is charged and evidence, or just a an act justifiabale to be sanctioned as a crime in tax administration only. This is also at the same time as an effective control to minimize potential abuse of authority and/or conflict of interest of certain persons who misuse the amount of discretion in the implementation of tax crime investigation. Some examples are displayed in the Supreme Court Cassation Decision No. 392 K/Pid. Sus 2014 dated 17 April 2014 who convicted two defendants who gave money amounting to around SGD600.000,- to officers of Tax PPNS, ED and MDIN, as an effort to stop the tax investigation of an Institutional Taxpayer, and the existence of a blackmail motive by the Tax PPNS with threats to harness the witness, as the operation of redhanded apprehension (OTT) conducted by the
Corruption Eradication Commission (KPK) against unscrupulous Tax PPNS, PR. ${ }^{47}$

In calculating the consequences or losses (in revenue) of the state generated through the disclosure of fraud, regulators and loss calculation experts are required to develop activities and apply appropriate calculation procedures and techniques according to the development of their findings by further reviewing the evidence (type of evidence, source of evidence, evaluation of evidence) with the tax laws and regulations that apply to then be prepared in the form of reports on the results of the calculation of the result or loss (in revenue) of the state. ${ }^{48}$ This means that, the competence of the expert, at least a tax regulatory expert and loss of state revenue expert, in determining that a suspected offense can cause the losses in the state's revenue can not be detached from his or her best knowledge which can explain the problem related in the form of opinions based on education or training as well as special work experience. ${ }^{49}$

This opinion is also reinforced by the opinion of Diaz Priantara who affirms that the legal requirement of expert opinion is the information given according to his/her knowledge, in accordance with his knowledge discipline, to their very best and the skills possessed must be obtained through formal education. ${ }^{50}$ More on the competence of an expert, it is very necessary that there exists a general and standard criteria in assessing these qualifications, as cited in the opinion of G. Jack Bologna and Robert J. Lindquist in Karyono who stated:

"Determining that given person is sufficiently knowledgeable and capable of serving as an expert depend on two factors: First, does the candidate possess the objective qualifications for job? Does he or she have the appropriate credentials relevant prior-experience and

\footnotetext{
43 Article 65 serta Article 116 paragraph (3) dan Article 116 paragraph (4) General Provisions of Indonesia Criminal Law.

Article 317 General Provisions of Indonesia Criminal Law.

Article 322 General Provisions of Indonesia Criminal Law.

Article 1365 General Provisions of Indonesia Criminal Law.

Beritasatu, "Terbukti Memeras PPNS Pajak Divonis Empat Setengah Tahun Penjara" www.beritasatu.com/hukum/148862-terbukti-memerasppns-pajak-divonis-empat-setengah-tahun-penjara.html, accessed on 5 July 2017.

Karyono, 2013, Forensic Fraud, Penerbit Andi, Yogyakarta, p. 153, 175, and 179.

Mark F. Zimbelaman, et al., Op.cit, p. 13

Diaz Priantara, 2013, Fraud Auditing and Investigation, Penerbit Mitra Wacana Media, Jakarta, p. 425.
} 
critical information that bears in success full resolution of the case? Second, does the expert though sufficiently qualified, have the personal characteristics to effectively function as part of investigative team?" 51

Furthermore, regarding the standard (quality measure), referring to the opinion of KH Spencer Pickett and Jennifer Pickett in Theodorus M. Tuanakotta, it is better that the experts]in providing the best possible information in connecting fraud and losses (in revenue) of the state must be able to refer at least at the following standards: ${ }^{52}$ (a). The process of giving opinion based on the best knowledge of said experts should be based on recognized best practices; (b). The collection of evidence underlying the opinion should refer to the principle of prudence so that it can be accepted in court; (c). Documentation is indexed so that it is easy to trace; (d). Since the proof in calculation of the loss (in revenue) of the state relating to the alleged tax crime is present to the expert at the time of the hearing, the expert should use his best knowledge to sort out between administrative law case or criminal law case; (e). Comprehensive understanding of their legal rights and obligations as experts and requirements regarding reporting.

In addition to expert opinions and quality standards, considering the basic existence of a criminal offense is the principle of legality and the basis of whether an offender can be criminalized is the principle of error ${ }^{53}$ and considering that the calculation of losses (in revenue) of the State, which is at least close to the material truth, identical to the tax year and/or tax period, then the Author opines that it is more useful ${ }^{54}$ and more thorough if the PPNS DGT in considering the tempus delicti of losses (in revenue) of the state as a continuing action of Article 64 paragraph (1) KUHP, ${ }^{55}$ either due to several years of unpublicized tax obligations that have not been issued by SKP and or related to new data which have not previously been disclosed (in the case of has been issued SKP) and or have not yet passed the tax criminal prosecution pursuant to Article 40 UU KUP. The application of Article 64 paragraph (1) in calculating the losses (in revenue) of the state as a reflection that between one act and another act is interrelated and constitutes a unity provided that it is a manifestation of a will of a forbidden decision and such action shall be of a similar nature (referring that such action falls under the same criminal provisions). ${ }^{56}$ The same thought is also put forward by A. Z. Abidin and Andi Hamzah who stated that the action continues to refer to the unity of the will on similar acts that have a time relationship factor (distance in time is not long). ${ }^{57}$

If the determination of the category of the act of administrative violation or tax crime can cause unequal treatment in calculating state losses as one of the elements of criminal offense of tax, even potentially causing conflict in the future. So it is necessary to explicitly and or at the very least an expert opinion of tax regulation and the expert on losses (in revenue) of the state in providing opinion to the best of his knowledge.

\footnotetext{
Karyono, 2013, Op.cit, p. 204.

52 Theodorus M. Tuanakotta, 2007, Akuntansi Forensik dan Audit Investigatif, Lembaga Penerbit Fakultas Ekonomi Universitas Indonesia, Jakarta, p. 52.

53 Teguh Prasetyo, 2010, Kriminalisasi dalam Hukum Pidana, Penerbit Nusa Media, Bandung, p. 49.

54 In the case of the calculation of the loss (on revenue) of the state, it is expected that the benefit is to contain legal certainty in which all actions undertaken are oriented to the intent and purpose of the legislation itself, as Jeremy Bentham in Muhammad Erwin and Amrullah Arpan, 2008, Filsafat Hukum: Mencari Hakikat Hukum, Penerbit Universitas Sriwijaya,Palembang, p. 41 and 42, emphasizes that the morality of an action must be determined by weighing the utility of achieving the happiness of mankind, John Stuart Mill in Astim Riyanto, 2010, Filsafat Hukum, Penerbit Yapemdo, Bandung, p. 716 and 717, emphasized that the measure of good and bad deeds should be measured in terms of benefits generated because the highest good is the utility. See Paul W. Taylor , "Justice and Utility", Canadian Journal of Philosophy, Vol. I, No. 3, March 1972, p. 347, defines benefit as "a necessary condition for the justifiability of social rules because the concept of utility is built into the very notion of an individual's having good reasons for committing himself to social rules."

55 Article 64 paragraph (1) General Provisions of Indonesia Criminal Law. which states: "If between several acts, although each is a crime or offense, there is a relationship that must be viewed as a continuing act, etc."

56 Eddy O. S. Hiariej, Op.cit., p. 346.

57 A. Z. Abidin and Andi Hamzah, Op.cit, p. 536.
} 


\section{Conclusion}

Based on the background and discussions as has been elaborated previously there can be drawn two conclusions. First, the existence of the offense element (possible) cause losses (on revenue) of the sate in the field of taxation in Indonesia contains more legal certainty (both to the Taxpayer and for tax authorities) when it is a material offense. This is in accordance with the nature of the criminal sanction of taxation which is ultimum remedium, and the necessity to fulfill the element (possibility) which cause losses (on revenue) of the state as regulated in Article 38, Article 39 paragraph (1), Article 39 paragraph (3), Article 39A UU KUP, and Article 24 and Article 25 paragraph (1) of UU PBB. The nature of ultimum remedium of criminal tax is expressly stipulated in Article 43A paragraph (1) and Article 1 subparagraph 26 of UU KUP stating that prior to the tax investigation, it must be through the examination of the preliminary evidence with one of its stages is to give the Taxpayer the opportunity to express his/her own unlawfulness in his/her actions. Even at the time of the investigation, the Taxpayer still has the opportunity to file a letter of application for termination of tax investigation as affirmed in Article 44B of UU KUP and PMK No. 55/PMK.03/2016, as long as it has not been transferred to court.

As with the criminal sanction of the ultimum remedium tax, in minimizing the conflict in calculating the element of loss (on revenue) of the state, it is expected that the assertion that the expert, who is capable, independent and objective is appointed by the Minister of Finance (as affirmed in Article 34 paragraph (4) and paragraph (5) of UU KUP, Article 44B of UU KUP, and PMK-55/2016) in the form of a Team with reinforced opinions in the form of reports prepared in accordance with the competent standards of taxation experts and counting experts on easy-to-find state revenues, worthy and appropriate to be recorded in the Expert Team's report and/or working paper. As to the present time, the regulation for experts in tax crime is still in the form of draft of Article 121 of KUP Bill which states that the calculation of the amount of state financial loss in the field of taxation is stipulated by the Head of Institution.

Second, the existence of the elements (possibility) of causing losses (on revenue) state in the criminal act of taxation in Indonesia has not been supported by strict regulation whether an act is said to be a violation of tax administration or a criminal act of taxation. Therefore in certain respects there is a dualism of treatment between the application of criminal or administrative sanctions which may cause obstacles in the calculation of a definite loss (on revenue) of the state to the parties concerned such as the PPNS DJP, the Public Prosecutor, the Panel of Judges, the Suspect/Defendant and the Expert who has been requested for expert opinions by PPNS DJP or Experts to relieve sentence appointed by the Suspect/Defendant. This leads to the need for information at least of the tax regulators and state loss (or revenue) experts who can explain that an act is a tax evasion, not a violation of tax administration. It is also desirable that the PPNS DJP, in the conduct of tax criminal investigations, to consider the tempus delicti of losses (on revenue) of the state in several period/tax year which is related to 'as a perpetual act', as long as the tempus delicti is novum (as has been issued by SKP) and or has not expired from the process of prosecution. 


\section{REFERENCES}

\section{A. Books}

Abidin, A. Z. and Andi Hamzah, 2010, Pengantar dalam Hukum Pidana Indonesia, Yarsif Watampone, Jakarta.

Directorate General of Taxation Republik Indonesia, 2015, Laporan Tahunan 2015, Directorate General of Taxation Republik Indonesia, Jakarta.

Directorate General of Taxation Republik Indonesia, 2014, Laporan Tahunan 2014, Directorate General of Taxation Republik Indonesia, Jakarta.

Erwin, Muhammad and Amrullah Arpan, 2008, Filsafat Hukum: Mencari Hakikat Hukum, Penerbit Universitas Sriwijaya,Palembang.

Karyono, 2013, Forensic Fraud, Penerbit Andi, Yogyakarta.

Hadjar, Abdul Ficar, et. al., 2014, Menghukum Pengemplang Pajak: Hasil Eksaminasi Publik atas Putusan Mahkamah Agung Dalam Perkara Tindak Pidana Pajak dengan Terdakwa Suwir Laut, The Indonesian Legal Resource Center dan Indonesian Corruption Watch, Jakarta.

Hiariej, Eddy O. S., 2014, Prinsip-Prinsip Hukum Pidana, Penerbit Cahaya Atma Pustaka, Yogyakarta.

Prasetyo, Teguh, 2010, Kriminalisasi dalam Hukum Pidana, Penerbit Nusa Media, Bandung.

Priantara, Diaz, 2013, Fraud Auditing and Investigation, Penerbit Mitra Wacana Media, Jakarta.

Riyanto, Astim, 2010, Filsafat Hukum, Penerbit Yapemdo, Bandung.

Schaffmeister, D., et al, 2007, Hukum Pidana, Citra Aditya Bakti, Bandung.

Tuanakotta, Theodorus M., 2007, Akuntansi Forensik dan Audit Investigatif, Lembaga Penerbit Fakultas Ekonomi Universitas Indonesia, Jakarta.
Manipulasi Laporan Keuangan, Penerbit Salemba Empat, Jakarta.

Zimbelaman, Mark F., et al., Translated by Novita Puspasari, et al., 2014, Akuntansi Forensik, Penerbit Salemba Empat, Jakarta

\section{B. Journal Articles}

Pramono, Widyo, "Penyamaan Persepsi Dan Kerjasama Dalam Pemeriksaan Di Bidang Perpajakan Untuk Mendukung Optimalisasi Penerimaan Negara", Yustisia, Vol. 5, No. 1, January - April 2016.

Taylor, Paul W., "Justice and Utility", Canadian Journal of Philosophy, Vol. I, No. 3, March 1972.

\section{Internet}

Beritasatu, "Terbukti Memeras PPNS Pajak Divonis Empat Setengah Tahun Penjara" $w w w$. beritasatu.com/hukum/148862-terbuktimemeras-ppns-pajak-divonis-empatsetengah-tahun-penjara.html, accessed on 5 July 2017.

National Legal Development Board of the Ministry of Justice and Human Rights of the Republic of Indonesia, "Laporan Akhir Penyelarasan Naskah Akademik Rancangan UndangUndang Tentang Ketentuan Umum Dan Tata Cara Perpajakan", http://www.bphn. go.id/data/documents/Penyelarasan-NARUU-Ttg-Ketentuan-Umum-\&-Tata-CaraPerpajakan.PDF, accessed on 29 March 2017.

Supreme Court of the Republic of Indonesia, "Putusan PN PEKANBARU Nomor 229/ Pid.Sus/2014/PN. Pbr Tahun 2014” https:// putusan.mahkamahagung.go.id/putusan/4e6 7ddd85f9ea66bdef51d16abeldd52, accessed on 28 June 2017. 


\section{Regulations}

Law No. 6 of 1983 regarding General Provisions and Procedure of Taxation as Has Been Amended Several Times Lastly by Law No. 16 of 2009 (KUP Law) (State Gazettes of the Republic of Indonesia of 2009 Number 62, Additional State Gazettes of the Republic of Indonesia Number 4999).

Law No. 31 of 1999 regarding Eradication of the Crime of Corruption (State Gazettes of the Republic of Indonesia of 1999 Number 140, Additional State Gazettes of the Republic of Indonesia Number 387).

Law No. 1 of 2004 regarding State Treasury (State Gazettes of the Republic of Indonesia of 2004 Number 5, Additional State Gazettes of the Republic of Indonesia Number 4355).
Law No. 15 of 2006 Regarding Badan Pemeriksa Keuangan (State Gazettes of the Republic of Indonesia of 2006 Number 85, Additional State Gazettes of the Republic of Indonesia Number 4654).

General Provisions of Indonesia Criminal Law.

General Provisions of Indonesia Civil Law.

Government Regulation (PP) No. 74 of 2011 regarding Procedure for the Implementation of Rights and Fulfillment of Tax Obligations (State Gazettes of the Republic of Indonesia of 2011 Number 162, Additional State Gazettes of the Republic of Indonesia Number 5268).

\section{E. Court Decission}

Constitutional Court Decision (MK) No. 003/PUUIV/2006 